\title{
IAMJ
}

INTERNATIONAL

AYURVEDIC

MEDICAL JOURNAL

ISSN: 2320-5091

Impact Factor: 6.719

\section{ALLEVIATING KNEE JOINT DISORDERS WITH AYURVEDIC JANU DHARA THERAPY - A REVIEW ARTICLE}

\author{
$\underline{\text { Avvinish Narine }}^{1}, \underline{\text { Rajendra Garg }}^{2}, \underline{\text { Kshiteeja Choudhary }}^{3}$, Gopesh Mangal $^{4}$ \\ ${ }^{1,2} \mathrm{PG}$ Scholar, Department of Panchakarma, National Institute of Ayurveda, Jaipur, Rajasthan, India \\ ${ }^{3} \mathrm{PhD}$ Scholar, Department of Panchakarma, National Institute of Ayurveda, Jaipur, Rajasthan, India \\ ${ }^{4}$ Associate Professor, Department of Panchakarma, National Institute of Ayurveda, Jaipur, Rajasthan, India
}

Corresponding Author: dr.anarine@icloud.com

https://doi.org/10.46607/iamj1209062021

(Published Online: June 2021)

Open Access

(C) International Ayurvedic Medical Journal, India 2021

Article Received: 19/05/2021 - Peer Reviewed: 09/06/2021 - Accepted for Publication: 10/06/2021

Check for updates

\begin{abstract}
Janu Dhara is an Ayurvedic procedure where lukewarm medicated oil is poured over the knee joint for a certain period with the help of a Dhara Patra. The word Janu refers to knee and Dhara means to pour, mainly medicated oil. It is a very unique procedure mentioned as 'Snehayukta Swedana' due to the fact that it comprises both Snehana (therapeutic oleation) and Swedana (sudation therapy). The Taila (oil) used for this procedure does the Snehana and due to the Agni Samyoga in this procedure it has the resulting Swedana effect. Janu Dhara is advised in painful conditions caused mainly by Vata Dosha, usually for degenerative diseases, stiffness associated with bone, joint and or musculoskeletal pains, it relieves swelling and inflammation in the knee joint. At the end of the procedure perspiration is noticed and an increased range of motion can be observed. Previous clinical studies also suggest the efficacy of Janu Dhara in knee joint pain. Janu Dhara helps to tone muscles, provides lubrication and improves the working mobility of the joint.
\end{abstract}

Keywords: Ayurveda, Janu Dhara, Knee Joint, Panchakarma

\section{INTRODUCTION}

Acharya Charaka ${ }^{1}$ has classified Trividha Aoushadhi as Anta-Parimarjana (internal therapies), Bahi-Parimarjana (external therapies) and Shastra-Pranidhana (therapies requiring surgical intervention). Janu Dhara is included in Bahi-Parimarjana type of treatment. Based on mode of application, the Bahya procedures may be classified into pouring type: medicated Kvatha, 
Ksheera or Sneha etc., are poured from a specific distance over the required places. It may be Ekanga like Janu Dhara or Sarvanga like Kayaseka. Snehana is the main Purvakarma (preparatory procedures) of Panchakarma (five bio-cleansing therapies). Literally Snehana means to oleate or to make smooth ${ }^{2}$. Acharya Charaka $^{3}$ has said that the procedure which causes unctuousness, fluidity, softness and moistness in the body is Snehana or Oleation therapy. The fatty substances used in this therapy are for the purpose of producing lubrication or oleating effect on the internal as well as external organs. This treatment has qualities like restfulness, strength, and invigoration and cognition. Generally, Sneha Dravya are having properties like Drava (fluidity), Sukshma (minuteness), Sara (mobility), Snigdha (unctuousness), Picchila (sliminess), Guru (heaviness), Sheeta (coldness), Manda (slowness) and $M r d u$ (softness) which are having antagonistic properties of Rukshana (dryness) Dravya ${ }^{4,5}$ Swedana is the process by which the sweat or perspiration is produced in the body by using various methods. Swedana is the procedure which relieves Stiffness, Heaviness and Coldness of the body and produces Sweating ${ }^{6}$. It is the specific treatment for a number of disorders especially in Vata dominant diseases. The drugs used for Swedana therapy should possess following properties - Ushna (hotness, Tejas Mahabhut Pradhana), Tikshna (sharpness), Sara (mobility), Snigdha (unctuousness), Ruksha (dryness), Sukshma (minuteness), Drava (fluidity), Sthira (stability) and Guru (heaviness).

\section{Materials Required}

The following equipment should be made available for conduction of the procedure.

- Droni or Dhara table- This is a waist high table that is used to perform Abhyanga as well as the Dhara procedure. The upper surface is shallow and concave. An outlet is located at the foot of the table. The top end of the table has a separate rounded part and the surface of the table also forms a concave slight depression.

- 2 Dharapatra or Sarawa (of 2 litre capacity) (as in Figure 1 Below)

- 2 Vessels of 3 litres capacity (1 litre more than the Dharapatra capacity)
- 2 Dry and clean towels.

- 2 litres of Medicated oil.

- 1 Helper to assist for changing the Medicated oil.

- Bowl of $150 \mathrm{ml}$ capacity for Taila dispensing.

- Wide mouthed vessel for indirect heating of Medicated oil.

- Gas stove /lnduction heater

- Warm drinking water if required by the patient.

- Cold water for sprinkling if any complications are observed.

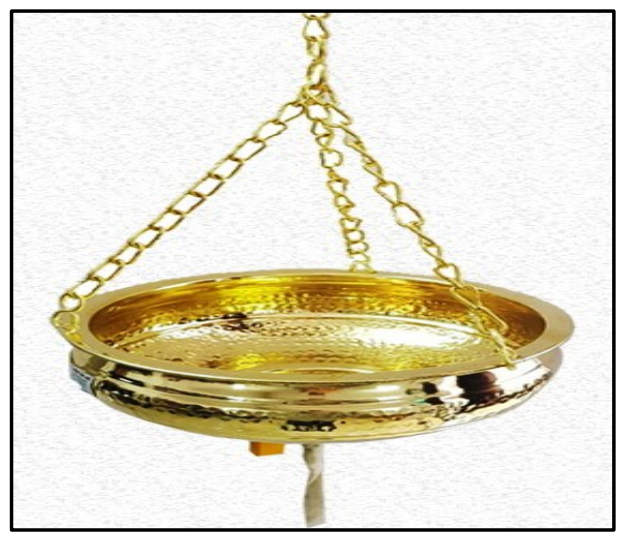

Figure 1: Dhara Yantra

\section{Procedure}

a) Examination of Patient: The patient is examined with reference to with Dashvidha Pariksha (Tenfold examination) and the Vyadhi (disease) as well as Deha Bala should be evaluated using Pratyaksha (direct perception), Aptopadesha (advice from the wise) and Anumana (inferential reasoning). The affected knee should be examined properly for abrasions and injuries, then the tender area marked.

b) Preparation of the Patient: The Dhara Karma is to be done in the morning hours after the evacuation of the bowel and bladder. The patient is made to lie down or to sit erect on the Abhyanga table. The affected knee joint is properly exposed. To begin with, the patient is subjected to local $A b$ hyanga procedure. The limbs are supported in a horizontal position ensuring that the patient is also comfortable. 
c) Main Procedure The bowl containing medicated oil is heated gently by keeping over hot water (water bath). The lukewarm Taila (having bearable warmth to the patient) is poured into the Dhara pot and made to flow on the Janu-Sandhi (knee joint) in a regular, steady stream. The height of the stream should be maintained at 12 Angula (approx. 9 inches) throughout the procedure. Mild massage should be done with left hand continuously along with the flowing oil. The medicated oil should be continuously taken and reheated in order to maintain the temperature throughout the procedure. The medicated oil can be used for three days consecutively and fresh oil should be used on every fourth day of the procedure.

d) Signs of Properly Administered Procedure: Samyak Lakshana of Janu-Dhara is not mentioned in classics. Since it is a type of Swedana and Snehana, Samyak Swedana and Samyak Snehana Lakshana can be considered. Among Samyak Swedana Lakshana Sheetoparama, Stambhanigraha, Gauravanigraha and Vyadhihani can be considered for assessment. In case of Samyak Snigdha Lakshana Snigdha Gatratva and Mrdu Gatratva can be taken for assessment.

e) Time Duration: The medicated oil should be poured for ten thousand Matra Kala. Hence the procedure is performed for 40-50 minutes each day, for 7 days, 14 days or 21 days.

f) Post Procedural Activities

- After the Taila Dhara, light Abhyanga is done over the Janu-Sandhi for about 5 minutes.

- Patient is advised to take rest for at least 15 minutes.

- Patient is permitted to take bath with lukewarm water after a minimum of 1-hour time has elapsed after procedure.

\section{MODE OF ACTION OF JANUDHARA}

The therapeutic action of Janu Dhara depends on: Procedural action of Swedana and the pharmacological action of the medicine. The actions of Swedana can be understood as

Stambhaghna: Swedana relieves Stambha (stiffness). Stambha is mainly caused by Vyana Vayu, Sleshamka
Kapha, Amarasa, Mamsa, Meda and Vasa. Vayu by Rooksha Guna absorbs Snigdhata so causes Stambha. Swedana by its Snigdha and Ushna Guna does Srotosuddhi (cleansing of micro channels) and Ama Pachana, thereby relieving stiffness.

- Gouravaghna: It causes excretion of watery content (Apya Ghataka) of the body through Swedana. Apya Tatva is Guru. Due to elimination, lightness is achieved.

- Sheetaghna: Swedana is chiefly Ushna (hot) and thus relieves Sheeta (coldness) by opposite property.

- Swedakarakatva: Swedana promotes sweating. Sweda is a type of Mala and impurities come out through it from the body. Swedana drugs by Ushna and Teekshna Guna are capable of penetrating the microcirculatory channels (Srotas) where they activate the sweat gland to produce more sweat.

- The dilation of the microchannels allows Laghu and Sara Guna to act on Dosha in the channels, to remove stagnation, to make the sticky content mobile to excrete them into micro pores in the form of sweat.

- Acharya Vagbhata said that the waste is removed from the body just as soap and hot water removes dirt from the cloth.

The pharmacological action of the medicine: Different drugs are used in various types of Dhara Karma. Swedana causes vasodilatation by which drugs enters into the body. According to Acharya Sushruta, each of the four Tiryakdhamani gradually divides up one hundred thousand times, making them countless. The body is connected to Romakoopa as well as the network. Veeryas from Abhyanga, Parisheka, Avagaha, Alepa etc. enter the body through them after they have undergone Paka in the skin with Bhrajaka Pitta. ${ }^{7}$

- MODERN VIEW Swedana operates as the metabolism of body increases. Swedana Ushna Guna expands the capillaries and increases the circulation. Increasing circulation increases waste disposal and increased absorption of Sneha or drugs by the skin. It also promotes the rehabilitation of muscles and heat management may have the hypo analgesic effects. 
- Increased Metabolism: Tissue heating speeds up chemical changes, i.e. body temperature. Sympathetic activities are also increased because of the increased body temperature. Hormones such as epinephrine, nor-epinephrine, cortisol, thyroid hormones are released because of increased sympathetic activity, thus speeding up the metabolism rate. The increased metabolism means that oxygen and food products are being increasingly demanded and waste products, including metabolites, are being produced. Two important mechanisms for reducing heat are employed when the temperature of the body is too high in Swedana Karma. They are-

- Vasodilation-When body temperature increases, a negative feedback action is activated in order to achieve a normal temperature. Higher blood temperatures stimulate thermal receptors that transfer nerve impulses to the present area of the brain that stimulates the thermal centre, in turn, and inhibits the heat fostering centre. The heat losing centre nerve impulses cause blood vessel dilation in the skin. So, radiation and conduction are used to lose excess heat to the environment. Due to vasodilation, blood flow through the area increases to supply the necessary oxygen and nutrients and remove waste products.

- Induction of Sweating: By hypothermic activation of sympathetic nerves, a high temperature of blood stimulates sweat glands of the skin, resulting in excessive sweating. Increased body temperature by one degree causes sufficient sweat to reduce the basic body heat production rate 10 times. Body temperature rises to over 2-3 degrees Celsius during Swedana Karma. The above-mentioned mechanism results in increased sweating. So, it can be inferred that the Ushna Guna of Swedana Karma leads to stimulation of sympathetic nervous system and there is vasodilation with increased sweating.

\section{DISCUSSION}

The general line of treatment mentioned for Sandhigata Vata $^{8}$ is Snehana and Swedana in the form of Janu Dhara, and it is a very promising therapy to relieve the symptoms. Dhara Karma is one of the treatment mentioned under Murdha Tail Chikitsa as Shirodhara. ${ }^{9}$ The same Dhara, when applied on any localised part then it is called as Ekanga Dhara (and named according to the part being treated i.e. Janu Dhara for knee joint). According to Acharya Sushruta, the Veerya of the Dravyas applied over the skin is absorbed by Tryagaami Dhamanis $^{10}$, which are present all over the body and are attached to Romakoopas. Swedana open these Romakoopas. These Dravyas are mostly Ushna, Teekshna, Laghu, in properties and thereby ascertain Kaphvatahara and Shopahara effects. Due to these properties oil reaches the target part. Hence these will be helpful in pacification of the vitiated Vata Dosha.

\section{CONCLUSION}

Janu Dhara is recommended in conditions like osteoarthritis, stiffness and pain of knee joints. It may help to increase blood circulation to the affected area, gets rid of Dosha imbalances, strengthens the muscles in the area, helps the release of toxins and reduces inflammation. Due to the effect of medicated oils used, the procedure of Janu Dhara pacifies Vata Dosha and thus is especially effective in Vata Vyadhi, making it an easy yet effective treatment in disorders related to the knee joint.

\section{REFERENCES}

1. Agnivesh, Charak Samhita, Vidyotini Hindi Commentary by P. Kashinath Pandey and Dr. Gorakhnath Chaturvedi Varansi:Chaukhambha Sanskrit Bhavan; Reprint 2008, Volume 1, Sutrasthana. 11/55.

2. Acharya Sushrutha: Sushrutha Samhitha with Nibandasangraha commentary by Dalhanacharya, edited by Vaidya Yadavji Trikamji Acharya \& Narayan Ram Acharya "Kavyathirtha", Published by- Chaukhambha Orientalia, Varanasi, 8th Edition 2005; Sutra Sthana Ch:5/3, pp19.

3. Vaidya Jadavaji Trikamji Acharya edited Charaka Samhita, Sutra Sthana, Chapter 22, shloka no. 11 Edition: Reprint 2008, Pub: Chaukhamba Surbharati Prakashan, K.37/117, Gopal Mandir lane, Post box No.1129, Varanasi (UP), Page No 120.

4. Pt. Hari Sadashiva shastri Paradakara Bishagacharya edited, Ashtanga Hrudaya, Sutra Sthana, Chapter 16, Shloka No.1, Reprint, 2007, Pub:Chaukhamba Surbharati Prakashan K.37/117, Gopal Mandir lane, post box No.1129, Varanasi (UP), Page No.243. 
5. Vaidya Jadavaji Trikamji Acharya edited Charaka Samhita, Sutra Sthana, Chapter 22, shloka no. 15 Edition: Reprint 2008, Pub: Chaukhamba Surbharati Prakashan, K.37/117, Gopal Mandir lane, Post box No.1129, Varanasi (UP), Page No 120.

6. Vaidya Jadavaji Trikamji Acharya edited Charaka Samhita, Sutra Sthana, Chapter 22, shloka no. 11 Edition: Reprint 2008, Pub: Chaukhamba Surbharati Prakashan, K.37/117, Gopal Mandir lane, Post box No.1129, Varanasi (UP), Page No 120.

7. Vridhha Sushruta, Acharya Sushruta, Nagarjuna, Chandrat, Sushruta Samhita, with Nibandhsangraha commentary of Dalhanacharya, edited by Acharya Jadavaji Trikamji, Reprint, Chaukhambha Krishnadas Academy, Varanasi, 2012. Sharir Stahna. 9/9

8. Ambika datt shastri, sushruta samhita of sushruta with ayurveda tatva sandipika hindi commentatory, chiktsa sathana, chapter 4, shlok no.8, chukhamba surbharati prakashan k.37/116, gopal mandir lane, post box no.1139, varanasi (up).

9. Kaviraja atridev gupta edited by vaidya yadunandana upadhyaya Astang haridya, sutra sathan, chapter 22, shlok no 23. Edition pub chukhamba surbharati prakashan, gopal mandir lane K37/116, post box no.1150, varanasi (up).

10. Ambika datt shastri, sushruta samhita of sushruta with ayurveda tatva sandipika hindi commentatory, Sharir sathana, chapter 9, shlok no. 9, chukhamba surbharati prakashan k.37/116, gopal mandir lane, post box no.1139, varanasi (up).

\section{Source of Support: Nil}

\section{Conflict of Interest: None Declared}

How to cite this URL: Avvinish Narine et al: Alleviating Knee Joint Disorders With Ayurvedic Janu Dhara Therapy - A Review Article. International Ayurvedic Medical Journal \{online\} 2021 cited June, 2021\} Available from: http://www.iamj.in/posts/images/upload/1227 1231.pdf 